This is an electronic reprint of the original article. This reprint may differ from the original in pagination and typographic detail.

Author(s): Litmanen, Tapio

Title: $\quad$ Environmental conflict as a social construction: Nuclear waste conflicts in Finland

Year: $\quad 1996$

Version:

Please cite the original version:

Litmanen, T. (1996). Environmental conflict as a social construction: Nuclear waste conflicts in Finland. Society \& Natural Resources, vol. 9(No. 5), 523-535.

https://doi.org/10.1080/08941929609380991

All material supplied via JYX is protected by copyright and other intellectual property rights, and duplication or sale of all or part of any of the repository collections is not permitted, except that material may be duplicated by you for your research use or educational purposes in electronic or print form. You must obtain permission for any other use. Electronic or print copies may not be offered, whether for sale or otherwise to anyone who is not an authorised user. 


\title{
Environmental Conflict as a Social Construction: Nuclear Waste Conflicts in Finland
}

\author{
Tapio Litmanen \\ Department of Sociology \\ University of Jyväskylä \\ Jyväskylä, Finland
}

This article is originally published in Society and Natural Resources vol 9 (1996), issue 5, 523-535.

\section{Why Study Nuclear Waste Conflicts?}

Several studies have reported a great public anxiety associated with nuclear power and nuclear waste (e.g., Dunlap et al., 1993; van der Pligt, 1992). People all over the world have become concerned about the risks of nuclear power. Nuclear accidents like the ones at Three Mile Island in the United States in 1979 and Chernobyl in the former Soviet Union in 1986 have given a glimpse of the kind of risks this source of energy entails. Recent empirical findings show that, of a wide variety of risky technologies, nuclear risks are perceived as the greatest (Rosa and Freudenburg, 1993, p. 56). These public perceptions contrast starkly with the nuclear industry's views, which emphasize the safety of the technology.

Nuclear power divides opinions; there are important differences between the attitudes of social groups. The relevant variables include education, age, sex, marital status, and occupation (Drottz-Sjoberg, 1991). Interestingly, attitudes toward nuclear power are more favorable than those toward nuclear waste. During the last decade several surveys 
have assessed public attitudes toward the management of high-level radioactive waste. The picture that emerges is uniformly negative (Kunreuther, Desvousges, and Slovic, 1988; Slovic, Flynn, and Layman, 1991; Vari, Kemp, and Mumpower, 1991; Dunlap, Kraft, and Rosa, 1993; Benford, Moore, and Williams, 1993).

To some extent, attitudes toward nuclear power are internally contradictory. For example, public fear of radioactivity is greater than the anxiety generated by statistically far more dangerous things, such as driving a car or smoking. This point is not made to belittle the problems of nuclear power or people's perception of risk. Surely the fear of nuclear energy is also based on rational facts. As psychological risk research has shown, people evaluate risks on the basis of a number of dimensions-for instance, whether they are volu ntary or involuntary, controllable or uncontrollable, potentially catastrophic or not (Slovic, 1987). People also understand that the nuclear power industry has to deal not only with technical, but also with political, social, ethical, and ecological, questions, and that only some of these problems have been solved. (Blowers, Lowry, and Solomon, 1991, pp. 13-29; Parker, et al., 1987, pp. 5-1-5-24; Berkhout, 1991).

The common notion in studies concerning nuclear waste policy is that the roots of the problems can be traced to earlier mistakes. From the beginning of civilian nuclear programs in the early 1950s, the seriousness of the issue has been underestimated. Governments and authorities were enthusiastic over the new source of energy and gave permission to civilian use of nuclear power before there were any proper plans for the handling of nuclear waste. The use of nuclear power rapidly increased in the second half of the 1960s and in the first half of the 1970s, but during these decades no progress was made on the nuclear waste question. Consequently, the number of political conflicts in nuclear power states increased in the 1980s (see, e.g., de la Bruheze, 1992; Carter, 1987, p. 1; Openshaw, Carver, and Fernie, 1989, p. xi; Blowers, Lowry, and Solomon, 1991, pp. 1, 34; Berkhout, 1991, pp. 3-4).

Although the problem has international dimensions, it is also important to focus on the local level. The treatment of nuclear waste and the siting of facilities have typically been followed by local protest. Across the industrialized countries, the issue has raised vigorous and organized opposition. In some countries it seems that massive local resistance has played a more important role in changing national nuclear waste policy than bigger environmental organizations. The fact that the phenomenon is repeated in different cultural settings makes it important to study local environmental conflicts (Blowers, Lowry, and Solomon, 1991, p. 25; Carter, 1987, p. 234; Percival, 1992, p. 211; Parker et al., 1987, pp. 5-18-5-19).

As Rosa and Freudenberg (1993, p. 54) point out, one thing that is certain is that nuclear technology has become the most controversial technology of our time. It is a social issue with cathartic dimensions, because it is symbolically related to many fundamental disputes: the relationship between the state and the individual, trust in science and the state apparatus, antagonism between capital and labor, and so on (Berkhout, 1991, p. 44). The issues of nuclear power and nuclear waste encapsulate many controversies of modern times. By analyzing nuclear waste conflicts social scientists can learn to understand better the present state of industrial societies.

The aim of this paper is twofold: The first part deals with different ways of seeing environmental conflicts and social movements. The problems of conventional theories are discussed, and it is argued that the analysis of an environmental conflict must discover the social interaction that constitutes the conflict. In other words, the analysis must conceptualize the conflict as a social construction. The second part of the paper focuses on 
the question of how this theory works. To answer this question, this paper examines three Finnish conflicts over the siting of a high-level nuclear waste repository.

\section{Conventional Ways of Conceptualizing an Environmental Conflict}

Public authorities have often felt helpless because there appears to be a rule that the public opposes all large construction projects. Important societal questions have to be solved-but how can they when people refuse to cooperate? One field where these problems emerge is the disposal of hazardous toxic substances produced by industry. It is rather difficult to solve the problem of hazardous waste when something must be done, but nobody wants the waste in his or her backyard .

There have been attempts to construct means of persuading local residents to accept hazardous waste management facilities. Compensation theory, among other approaches, has tried to solve the problem by offering people economic benefit in compensation for the risk they will endure. The problem is that people living near a hazardous waste treatment facility do not calculate risk as defined by the cost-benefit model of compensation theory (Grossman and Cassedy, 1985; Portney, 1985; Kunreuther et al., 1990; Sigmon, 1987); people will not accept the risk at any price.

Increasing interest in environmental questions has produced a great number of studies of environmental conflicts. In Finland, for instance, these studies have yielded a great deal of important information about what happens in such conflicts, how people act for their environment, and which groups are important in the conflicts (see Litmanen, 1994b, p. 52). However, the lack of adequate theoretical conceptualization is evident. The phenomenon is new, and it has been difficult to find the right tools for understanding it.

One conventional way to conceptualize environmental conflicts is known as NIMBY (Not In My Backyard) (Armour, 1984). The focus here is on the public's negative reactions against any waste facility, and it is mainly the location, not the technology, that is seen as the problem. Another approach, LULU (Locally Unwanted Land Usage), understands environmental disputes in the sense of land use. In cases concerning the placemen $t$ of hazardous waste, the model reduces the conflict to the unwillingness of local residents to provide land for that purpose. Researchers adopting this perspective emphasize that there will be local opposition to such projects in any case, because the technology and the characteristics of the facility are so controversial.

However, as Freudenburg and Pastor (1992) have pointed out, the various NIMBY approaches include different implicit assumptions. They found three main views behind the NIMBY perspectives, which they called "public ignorance/irrationality," "public selfishness," and "public prudence." These categories correspond roughly to the stages of research on the NIMBY/LULU issue to date. During the first phase, the ignorance/irrationality perspective was the most influential. As the volume of empirical research grew, it became evident that the public should not be viewed as ignorant. In the second and current phases, researchers have moved away from blaming the inhabitants toward understanding them. This has resulted in two bodies of literature, one emphasizing the selfishness of the public and the other viewing public reactions as prudent and meaningful.

Some observers see local opposition to large projects as a selfish, conservative reaction against responsible policy that accords with the common interest. Although analyses from this viewpoint have been more neutral than those representing the ignorance/irrationality perspective, they too have met with much criticism in the wake of new research (Freudenburg and Pastor, 1992; Petts, 1994). For example, Lake and Johns (1990) have pointed out that these models conceptualize the conflict as a dualistic situation in which 
local and public interests clash. Governmental authorities represent societal interests, including safety and a healthy environment, whereas local authorities and citizens represent parochial interests tied to protecting the community ambience, social status, economic investment, and local environment. Thus, in the explanation of conflicts over the siting of hazardous waste, these models place the onus for the conflict on "myopic local communities" blocking the "unimpeachable objectives" of good health and a clean environment for everyone. (See also Sigmon, 1987, pp. 177-178; Blowers, Lowry, and Solomon, 1991, pp. 13, 19; Lidskog and Elander, 1992, pp. 255-256; Lidskog, 1993, pp. 572-573; Lake, 1993, p. 89.)

To assume that the opposition to a repository is only a selfish NIMBY reaction reduces the complexity of the conflict. True, there seems to be general correspondence between an opposition group on the one hand and certain interests, knowledge, and concerns on the other, but on closer examination it is evident that the opponents exhibit a wide variety of interests and concerns. As Petts (1994, p. 209) has pointed out, some expressions of concern are tightly connected to the issue, whereas others are more loosely related to the project or have more to do with other local or political issues. Thus, during the planning and implementation of a project, the debate is changing all the time as new issues come to the fore. The strategic situation changes when some interested parties leave the discussion and new ones enter.

To view public reactions as prudent is a more recent approach. Instead of being skeptical toward public concerns, here the researcher takes these concerns seriously and sees that residents can inform planners about the social, psychological, ethical, and political questions revolving around the siting process. Protests against a facility express real concern, which must be thoroughly examined. For instance, Vari, Kemp, and Mumpower (1991, p. 88) analyzed such public responses in three countries and divided public concerns into five categories: (I) health and safety, (2) economic, (3) environmental, (4) social, and (5) technical -procedural. Kemp (1990, p. 1254) found that typical vocabularies of opposition to the disposal of radioactive waste comprise four categories: (I) perceived risks and safety, (2) local economic impact and/or blight, (3) health and environment, and (4) public distrust.

Environmental threats to human health and safety give birth to conflicts, but the environmental policy literature reveals a pervasive dissension about the real nature of environmental conflicts. Dietz, Stern, and Rycroft (1989, p. 49) list four current definitions of such conflicts: (1) differential knowledge, (2) vested interest, (3) value conflict, and (4) mistrust of expert knowledge. As they have shown (1989, p. 52-53), these kind of oversimplified explanations serve a political function. Different definitions of conflict have an implicit answer to questions about the truthfulness and legitimacy of actors. It is important to understand that the definition a researcher adopts sets a specific agenda for research, and that the study also tends to validate the theory he or she has chosen. However, the definitions and explanations are also ideal categories that promote understanding of the cases by simplifying them. In a closer examination, it becomes apparent that different definitions are an integral part of a set of explanations of an environmental conflict; moreover, these definitions are continuously changing. In nuclear waste conflicts definitions vary from time to time, and the actors' definitions change with changes in the circumstances (Petts, 1994). Therefore, it is important to adopt an approach that is sensitive to the various definitions given by the different parties to the conflict. To get a grip of social definitions, a theory must have an epistemological orientation and emphasize the sociology of knowledge, as does social constructionist theory. 
Current theories of social movements and environmental conflicts have revealed the importance of the dynamics behind movements and conflicts. To treat movements and conflicts as "things" can trap the researcher in epistemological or methodological misunderstandings. An analysis of an environmental conflict must discover the system of internal and external relationships that constitute the action, not reduce the scene to a dualistic situation, as in the dichotomy between general versus particular interest (NIMBY). In other words, the analysis must conceptualize the movement or the conflict as a social construction.

In the field of social movement research, the dominant paradigms (new social movement and resource mobilization theories) have concentrated mainly on structural factors behind movements and on micromobilization, networks, and resources, which are seen as the most important factors influencing the success or failure of movements. In addition to these approaches, the so-called identity theorists and social constructionists have been interested in the collective identities, knowledge production, and dynamics of social movements (Melucci, 1989; Eyerman and Jamison, 1991). The field of environmental conflict research seems to have u ndergone a similar development. Dietz, Stern, and Rycroft (1989) examined the social construction of conflicts over environmental health and safety issues. They concluded that every actor in a conflict tends to give the issue definitions that are parallel with his or her own values and political interests, legitimating the resources these groups possess in relative abundance. Lake and Johns (1990) analyzed the hazardous waste law and siting problem as a social construction. They found out that the particular form that hazardous waste law takes in a particular place represents the political resolution of conflict among different agencies of the state responding to competing sources of legitimation. Lidskog (1993) showed how, in the siting of a certain hazardous waste management facility, the important factor was the way actors understood the facility and what kind of definitions they gave to it. According to him, the dominant definition (supported by the power company) was economic, and local authorities and the definitions held by local residents were underestimated. He argues that when studying an environmental conflict one has to pay attention to different actors and their perspectives on the issue. Furthermore, one has to determine which definitions have a dominant status and through what kind of processes they gain their dominance.

\section{The Cases of Nuclear Waste Conflict in Finland}

To show the advantages of social constructionism, this paper examines three cases of environmental conflict in Finland. The Finnish power company Teollisuuden Voima Ltd. (TVO) began studying the suitability of the bedrock for a nuclear waste facility in different parts of Finland in the early 1980s. Nuclear waste conflicts arose in the municipalities of Kuhmo, Aanekoski, and Eurajoki at the end of the 1980s (Figure 1). The power company announced plans in December, 1992, to continue its investigations in these three communities. In the following year it further included Kannonkoski, a municipality adjacent to Aanekoski, in the research program. Without exception, the search for a suitable place for a high-level nuclear waste disposal plant has given birth to disputes and organized protest groups in these municipalities.

\section{Methods and Data}

The aim here is to analyze, from the social constructionist perspective, the process of perceiving nuclear waste in the municipalities mentioned above. The analysis of the environ- 


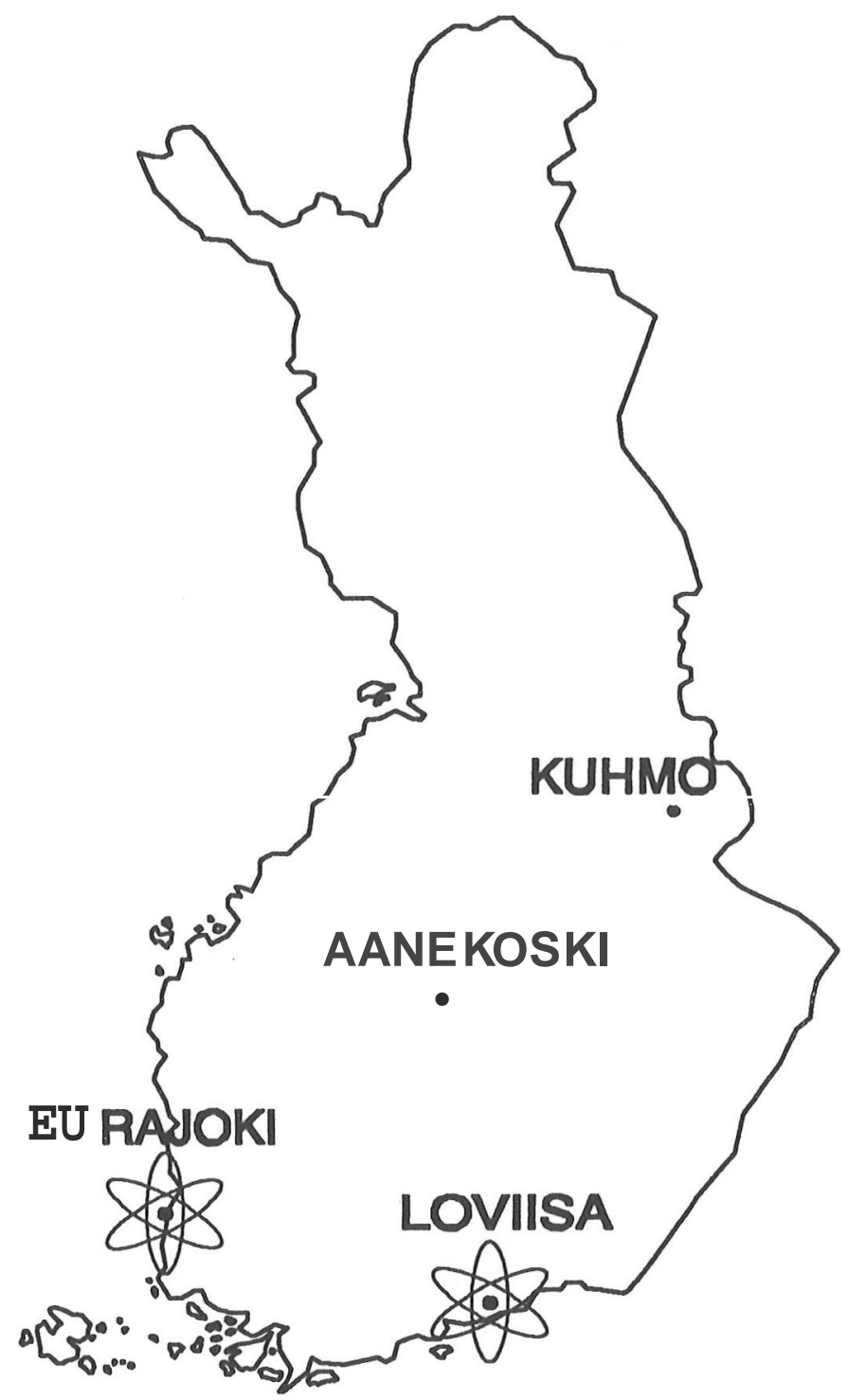

Figure 1. The locations of nuclear power stations and possible high-level nuclear waste facilities in Finland.

mental conflicts will concentrate on the struggle over definitions, which occurs on two levels: social definition of nuclear waste and social definition of the nuclear wasteconflict. But how does the social definition of nuclear waste happen in practice? Bijker (1992) has studied technical artifacts as social constructions and argues that it is important to identify the relevant social groups involved in the shaping of the artifacts. Hismain idea is that an artifact is characterized by interpretative flexibility, meaning that the relevant social groups give different definitions to it (Bijker, 1992, pp. 75-76). This paperargues that nuclear waste also has interpretative flexibility, allowing different social groups to add their definitions to the object. 
As a material object nuclear waste consists of radioactive elements, "radionuclides," capable of releasing ionizing radiation (alpha particles, beta particles, and gamma rays). All forms of ionizing radiation are harmful to human beings. In the environmental conflict this material object becomes part of the social world, and the social definition of it begins. Although the material object (nuclear waste) itself is located far away from local people's everyday lives, the social object constructed of it is not. During the conflict social groups give the object different meanings, some very similar to earlier definitions, others more imaginative. It can be said that in the environmental conflict a material object becomes a social object. In the potential host communities studied here, nuclear waste is constructed as a meaningful social object within the limits of material facts. An analysis of these cases as processes reveals how local action groups use, produce, and reproduce knowledge of the environmental controversy and how the social object is formed.

The interpretative flexibility of nuclear waste means that one can add many definitions to it (cf. Slovic, Flynn, and Layman, 1991; Vari, Kemp, and Mumpower, 1991; Litmanen, 1994a), which are linked with the definitions of the conflict. The three environmental conflicts analyzed in the following are seen as struggles over scientific-technical, economic, and political definitions of the object and the conflict (cf. Dietz, Stern, and Rycroft, 1989, p. 62). Pronuclear groups tend to support economic and scientific-technical definitions, whereas antinuclear groups try to shake the foundations of these definitions and give more room for political definitions. When a conflict is defined as scientific-technical, the legitimate resource is scientific and technical expertise. In conflicts over hazardous waste management, this definition tends to dominate, and therefore opposition has to adopt the same way of thinking or to break the monolithic definitions by using other definitions, such as political ones. When a conflict is defined as political, there is more space for arguments rising from people's everyday lives and experiences. From the beginning, the way in which nuclear waste and conflict are defined determines which arguments are legitimate, who are the legitimate participants in the conflict, and in what kind of arena the conflict is played.

The study of Eurajoki, Aanekoski and Kuhmo is based on the data gathered from the local newspapers, but also uses interviews $(N=16)$ of participants in the conflicts and the documents of local authorities (Litmanen, 1994b). For studying the social definition of issues on the local level, local newspapers serve as good sources, because they reflect the discussion quite well. For a firm grasp of the process of social definition, it is important to gather data over a sufficiently long period. Therefore, the author systematically collected all the discussion in Kuhmolainen, the local newspaper in Kuhmo ( $N=244$, consisting of news items, letters to the editor, etc.), from the period 1985 to 1993 . The data on the case of Aanekoski come from the local newspaper Sisa-Suomen Lehti, also covering the period 1985 to $1993(N=$ 108). Articles and readers' columns in the newspapers Satakunnan Kansa and Lansi-Suomi (N =64), from the period 1990 to 1993, represent the discussion about nuclear waste in Eurajoki.

The analysis of the data took place in three phases. First, chronological lists of the events, writings, and speeches related to each case were compiled. These lists were sorts of maps to show how different discussions continued and who were the main actors in each discussion. Then the story of each case was reconstructed, with emphasis on the struggle over definitions. The struggles were then sorted into three main categories: scientific, economic, and political. (Litmanen, 1994b).

\section{Eurajoki}

The case of Eurajoki differs from the other two environmental conflicts in that the municipality houses two of Finland's four nuclear power reactors. The small municipality is a 
"nuclear oasis" (cf. Blowers, Lowry, and Solomon, 1991, p. xviii), that is, a municipality that is strongly dependent on the nuclear power industry. In these kinds of communities there are usually nuclear reactors and both civil and military reprocessing centers. A great deal of the local residents derive their livelihood from the nuclear industry. A good example is Sellafield, UK, with its 11,000 employees in an area with few alternative occupations.

Historical developments made the manorial community of Eurajoki a nuclear oasis in 1979. Eurajoki now houses two nuclear reactors and low-level radioactive waste disposal facilities, but no civil or military reprocessing center. Although the nuclear power company does not have the same kind of authority as the lords of the manor had in former times, local authorities and residents still must listen to what the company says. This power is based on the fact that one third of the municipal tax revenue comes from the company, many residents work for it, and some of TVO's employees are representatives in the local council. Because of its good economic situation, the municipality has been able to invest quite extensively in the local infrastructure.

In Eurajoki the company has the strongest impact on the definition of nuclear waste. Almost every individual in the community agrees that the company greatly affects the well-being of the inhabitants. Thus, it is natural that economic values are strongly attached to nuclear power. Despite this advantage, the company has not succeeded in changing people's attitudes toward high-level nuclear waste.

Opposition to high-level waste can be traced to the beginning of the 1970s. When the local authorities gave permission for the construction of the nuclear power plant, they at the same time decided to forbid the storage of high-level radioactive waste in the municipality. When the construction decision came to a vote in the local council, the supporters of nuclear power won by one vote. Because of strong opposition to the project, before the final vote TVO had promised to store the proposed reactor's waste elsewhere.

In Eurajoki, nuclear power has thus been defined as an economic issue, although environmentalists have tried to show the risks of the plant. Public trust in the company's expertise and in its scientific-technical definitions dominates. Risks are connected in the public's mind to high-level nuclear waste, not to nuclear power itself. But gradually, trust has grown in the company's ability to handle nuclear waste. All local councils confirmed the rejection of radioactive waste until 1994, when the decision not to provide a facility for high-level waste was withdrawn.

\section{Kuhmo}

The social definition of nuclear waste in Kuhmo began in 1985, when a local newspaper of this northern mu nicipality reported that the town was one of the possible sites for radioactive waste. At that time TVO was examining 102 areas in different places in Finland, but this did not prevent a local journal from writing about the economic benefits of the project. The possible construction of the facility was discussed within the framework of employment. According to the newspaper, the construction could provide work for 200 people in the year 2010, and the use of the facility could employ over 100 people in the period 2020 to 2060 .

Only a week later the interpretative flexibility of nuclear waste was put to a test. The first reaction came not from a local resident, but from a person living in southern Finland and planning to move to Kuhmo. His definition of nuclear waste included ecological threats and interregional inequity. According to him, the construction of the waste disposal plant in Kuhmo would amount to one more case in the history of the exploitation of 
northern people and nature. Southern authorities and companies had for a very long time been destroying the forests of the region, he lamented, and now nuclear waste threatened what remained of its beautiful nature. The foundations for the conflict for years ahead were now established.

Despite the critical voices, the economic definition was so strong that in 1987 the municipality gave TVO permission to continue investigations in its territory. TVO had tried to strengthen the economic definitions by announcing that it would invest 8 to 10 million Finnish marks (about U.S. \$1,86 to 2,32 million) in investigations in Kuhmo. The direct benefit to the town would be FM 50,000 to 100,000 (U.S. $\$ 11,600$ to 23,200 ) in the form of taxes, and the investigations would give work for 5 to 10 people. TVO pointed out that the benefits would be greatest if the facility actually were constructed; the con- struction would bring the municipality FM 1 to 3 million (about U.S. $\$ 230,000$ to 700,000) in the form of tax revenue.

The critical voices emphasized the meaning of nature to the identity of the residents and to the economic well-being of the town. Dominant pronuclear economic definitions were also challenged by other economic definitions. Antinuclear definitions included arguments such as, "Nuclear waste would have a negative effect on tourism and on the image of the town in the middle of wilderness and beautiful nature."

In December 1987 the arena of the environmental conflict shifted. First the municipal health authority, and soon afterwards four village committees, appealed to the local council to forbid the storage of nuclear waste. The local council was subjected to strong pressure. The conflict was now defined as a political issue, and its participants had to try to persuade both the council and the public to accept their views. The mayor tried to stifle both the public's and the authorities' discussion, but the Board of Environmental Issues took the initiatives seriously. It handled the issue critically and decided not to support the construction plans. The arguments used against nuclear waste were: problems in the transportation of waste, unequal distribution of risks, and negative effects on the town image. TVO made a thorough reply, in which all the problems the board had mentioned were said to be avoidable. The company had realized that its favorable economic definition of nuclear waste was threatened by a definition according to which the nuclear waste facility would have an adverse effect on tourism. Thus, in its reply the company especially emphasized the positive effect of the facility on tourism and on the image of the town. It was in the interest of TVO to keep scientific-technical and economic definitions working in the project's favor.

But the snowball had been pushed downhill, and it was too late to stop it. The initiatives opposed to the siting of the facility had started to put pressure on the local council and local government. The lobbying finally resulted in a decision in principle to forbid the construction of the disposal plant. At the time of writing, TVO was still investigating the bedrock in Kuhmo, and the citizens' initiative was trying to keep the economic definition of nuclear waste negative by arguing that the planned project would destroy the image of the town and have a negative impact on tourism.

\section{Aanekoski}

The foundations of the Aanekoski case are different from those of Eurajoki and Kuhmo. First of all, in each of the latter two the locality of the environmental conflict has been stable, but in Aanekoski the social construction of the locality itself became an important element of the struggle over nuclear waste. In 1987 TVO started investigations in a small municipality called Konginkangas, which desperately needed more industries, jobs, and 
taxpayers. Later, as the economic situation of the municipality further deteriorated, it was merged into the neighboring town, Aanekoski. The second peculiarity of this case is that from the beginning the Konginkangas residents who were opposed to nuclear waste understood that they could not handle the case by themselves. Thus, they asked for help from the neighboring municipalities, and two local nature conservation associationsstarted to work on the side of this citizens' initiative. Because of these two events, the locality of the environmental conflict changed and affected the case. On the one hand, the alliance between the citizens' initiative and the nature conservation associations provided the opposition with more resources to challenge the scientific-technical definition of nuclear waste. On the other, the change of arena from a rural municipality to an industrialized environment strengthened the economic definition of nuclear waste.

The first aspect can be seen in the explanatory memorandum of the petition of the local inhabitants. The alliance chose the strategy of attacking the scientific-technical definitions promulgated by TVO, arguing against the waste disposal plant on scientific grounds and appealing to statements of the United Nations Scientific Council. It also invited a few scientists to an open meeting to express their views against the waste storage plans. The arguments of these "counter-experts" then spread to the public through the media.

In December 1992 TVO included Konginkangas in the next phase of the bedrock investigation program. In January 1993 the small mu nicipality was integrated into the town of Aanekoski. In this situation the economic aspects of nuclear waste continued to dominate. Because of the larger town's long association with the wood and paper industry, all industrial enterprises were welcomed to the town to alleviate the unemployment problem . (The unemployment rate of Aanekoski was $26.6 \%$ in 1993.) The town did not make the same kind of negative decision in principle as Eurajoki and Kuhmo, partly because of the potential economic benefits of the facility. The town authorities calculated the amount of municipal taxes the company would pay if the disposal plant were constructed, and estimated the annual increase at around FM 7 million (U.S. \$1,63 million). Especially paper workers and leftists believed that the nuclear waste facility would be important because of the jobs and welfare it would produce.

\section{Nuclear Waste Conflict as a Social Construction}

What can be concluded from these cases? Is it worthwhile to view environmental conflict as a social construction, and if so, how does the social definition take place? Instead of conceptualizing environmental conflict as a static still life, social scientists need to understand that such conflict is a process during which nuclear waste is constructed as a meaningful social object within the community. The conflict is a sort of learning process in which residents get more information, discuss the issue, and produce new interpretations and meanings. The interpretative flexibility of nuclear waste allows the residents to add to the earlier definitions a variety of meanings, which can stem from everyday experience, local traditions, and special circumstances, or from general knowledge produced by scientists and experts.

The other level in the struggle is how environmental conflict itself is defined. A good example of the social definition of a conflict is the social construction of the locality. A conflict's boundaries tend to follow the boundaries of the municipality or local administrative boundaries, but in the actual conflict these can be questioned as well. In Aanekoski, the boundaries of the conflict shifted twice: First a citizens' initiative allied with two nature conservation associations and managed to stir up the discussion in the 
neighboring municipalities, and then the merging of the municipalities of Konginkangas and Aanekoski added fuel to the fire. Before the integration, the residents and authorities of Aanekoski had not been interested in the question of nuclear waste, but with integration in 1993 TVO's investigations "came closer," although the real site continued to be located 15 kilometers away from Aanekoski.

Definitions include different cultural symbols through which they are linked with different value and belief systems. Definitions thus also affect the position of outsiders and their evaluations. They determine who are legitimate actors in a conflict and what kind of arguments are legitimate in the discussion. The parties to an environmental conflict tend to support definitions that are coherent with their values, that give space for their own group and keep others outside, or that limit the space of opposition and enhance the resources of their own group. For example, certain professions legitimate their resources by defining issues in a way that is parallel to their expertise; in this case legitimate arguments consist of scientific facts and research findings. (Dietz, Stern, and Rycroft, 1989, pp. 48-52.)

The social construction of local definitions is tightly connected with broader discourses. Although this paper has concentrated on the local level, readers should bear in mind that these processes unfold on other levels as well. Social scientists should leave behind socially insensitive perspectives that blame the victims and take the worries that local residents express seriously. As Freudenburg and Pastor (1992) have pointed out, even more important is to see local conflicts from the wider perspective of the larger system that creates victims and victimizations in the first place.

The social definition of nuclear waste has been evolving for decades on both international and national levels. Science communities, nuclear power organizations, nuclear power enterprises, environmental movements, parties, governments, and so on have had the strongest influence on the definitions. Analyzing this process, de la Bruheze (1992) has shown how nuclear waste became a problem in the United States. In fact, it became a problem because the issue was initially defined as unproblematic. In the period from 1945 to 1960, the U.S. Atomic Energy Commission was in the position to consolidate a definition that emphasized rapid development of technological expertise and limited the nuclear issue to a small technocratic elite. This strategy succeeded in bureaucratizing and technologizing the nuclear waste question until the definition broke down and the issue became a political problem in the 1970s. On the international level, the development has been very similar to de la Bruhezes's description of the American case (Carter, 1987).

Much of the social science literature about hazardous waste deals with such questions as how the siting should be done. This kind of social engineering approach needs to be complemented by social theories in which the conflicts over high-risk technology and the siting of facilities are placed into a wider context. Promising directions include SCOT (Social Construction of Technology) and PCOT (Political Construction of Technology), where the basic assumptions are that there will always be conflicts over technology and that technology is always shaped in social and political processes. Each technology thereby reflects and to some extent embodies the social order and the dominant social values of the culture (de la Bruheze, 1992).

These kinds of analyses show that the days of strongly biased NIMBY perspectives are numbered. Sophisticated studies of environmental conflicts have shown that many of the local public views expressed reflect several concerns that should be taken into account in the formulation and reformulation of nuclear waste policy. The role of social scientists in this process is to interpret conflicts and concerns from a wider perspective of social theory. The constructionist theory is not the only way forward; there are also other general 
theories - for instance, the neo-Weberian (Freudenburg, 1993; Perrow, 1984), modernization (Giddens, 1990, 1992), and systems theory (Luhmann, 1989) as well as the tehories of risk society (Beck, 1992; Perrow, 1984) - that can be applied to environmental controversies. In any case, it will be useful to give constructionist theory a change to develop a more sensitive instrument for analyzing public opposition to largescale projects.

\section{References}

Armour, Audrey. (ed.) 1984. The Not-In-My-Backyard syndrome. Ontario: Faculty of Environmental Studies, York University.

Beck, Ulrich. 1992. The risk society: Towards a new modernity. London: Sage Publications.

Benford, Robert D., Helen A. Moore, and J. Allen Williams, Jr. 1993. In whose backyard?: Concern about siting a nuclear waste facility. Sociological Inquiry I :30-48.

Berkhout, Frans. 1991. Radioactive waste: Politics and technology. London and New York: Routledge.

Bijker, Wiebe E. 1992. The social construction of fluorescent lighting, or how an artifact was invented in its diffusion stage. In Shaping technology/building society. Studies in sociotechnical change, eds. W. E. Bijker and J. Law, pp. 75-102. Cambridge, MA, and London: The MIT Press.

Blowers, Andrew, David Lowry, and Barry D. Solomon. 1991. The international politics of nuclear waste. Hampshire, UK, and London: Macmillan.

Carter, Luther J. 1987. Nuclear imperatives and public trust: Dealing with radioactive waste. Washington DC: Resources for the Future.

de la Bruheze, Adri. 1992. Political construction of technology: Nuclear waste disposal in the United States, / 945-1972. WMW-publikatie 10. Enschede, The Netherlands: Faculteit wijsbegeerte en maatschappijwetenschappen, Universiteit Twente.

Dietz, Thomas, Paul C. Stern, and Robert W. Rycroft. 1989. Definitions of conflict and the legitimation of resources: The case of environmental risk. Sociological Forum 1:47-70.

Drottz-Sjoberg, Britt-Marie . 1991. Perception of risk: Studies of risk attitudes, perceptions and definitions. Stockholm: Stockholm School of Economics, Center for Risk Research.

Dunlap, Riley E., Michael E. Kraft, and Eugene A. Rosa (eds.). 1993. Public reactions to nuclear waste: Citizens' views of repository siting. Durham, NC, and London: Duke University Press.

Eyerman, Ron, and Andrew Jamison. 1991. Social movements: A cognitive approach. Padstow, UK: Polity Press.

Freudenburg, William R. 1993. Risk and recreancy: Weber, the division of labor, and the rationality of risk perceptions. Social Forces 4:909-932.

Freudenburg, William R., and Susan K. Pastor. 1992. NIMBYs and LULUs: Stalking and syndromes. Journal of Social Issues 4:39-84.

Giddens, Anthony. 1990. The consequences of modernity. Cambridge: Polity Press.

Gicidens, Anthony. 1992. Modernity and self-identity: Self and society in the late modern age. Cambridge, UK: Polity Press.

Grossman, P. Z., and E. S. Cassedy. 1985. Cost-benefit analysis of nuclear waste disposal: Accounting for safeguards. Science, Technology \& Human Values 4:47-54.

Kemp, Ray. 1990. Why not in my backyard?: A radical interpretation of public opposition to the deep disposal of radioactive waste in the United Kingdom. Environment and Planning 2. 1239-1258.

Kunreuther, Howard, William Desvousges, and Paul Slovic. 1988. Nevada's predicament. Public perceptions of risk from the proposed nuclear waste repository. Environment 8: 16-20, 30-38.

Kunreuther, Howard, Douglas Easterling, William Desvousges, and Paul Slovic. 1990. Public attitudes toward siting a high-level nuclear waste repository in Nevada . Risk Analysis 4:469-484 .

Lake, Robert W. 1993. Rethinking NIMBY. American Planning Association Journal 59 (Winter):87-93. 
Lake, Robert W., and Rebecca A. Johns. 1990. Legitimation conflicts: The politics of hazardous waste siting law. Urban Geography 5:488-508.

Lidskog, Rolf. 1993. Whose environment? Which perspective? A critical approach to hazardous waste management in Sweden. Environment and Planning 25: 571-588.

Lidskog, Rolf, and Ingemar Blander. 1992. Reinterpreting locational conflicts: NIMBY and nuclear waste management in Sweden. Policy and Politics 4:249-264.

Litmanen, Tapio. 1994a. Sievin Suojelijat ydinjätteitä vastaan [Sievin Suojelijat against nuclear waste]. In Pasilasta Vuotokselle, eds. P. Rannikko and A. Lehtinen, pp. 238-256. Tampere, Finland: Gaudeamus.

Litma nen, Ta pio. 1994b. Kallion uumenissa, satojen metrien syvyydessä: Paikalliset ydinjätekonfliktit Suomessa [In the bowels of the bedrock, hundreds of meters deep: Local nuclear waste conflicts in Finland]. Licenciate's thesis in sociology, University of Jyväskylä, Jyväskylä, Finland.

Luhmann, Niklas. 1989. Ecological communication. Cambridge, UK: Polity Press.

Melucci, Alberto. 1989. Nomads of the present: Social movements and individual needs in contemporary society. Philadelphia: Temple University Press.

Openshaw, Stan, Steve Carver, and John Fernie. 1989. Britain's nuclear waste: Siting and safety. London and New York: Belhaven Press.

Parker, Frank L., Roger E. Kasperson, Tor Leif Andersson, and Stephan A. Parker. 1987. Technical and socio-political issues in radioactive waste disposal: Volume /, Safety, siting and interim storage. SKN-Report 17/1987. Stockholm: Statens Kiirnbriinsle Niimnd.

Percival, Robert V. 1992. The ecology of environmental conflict: Risk, uncertainty and the transformation of environmental policy disputes. Studies in Law, Politics, and Society 12:209-246.

Perrow, Charles. 1984. Normal accidents: Living with high-risk technologies. New York: Basic Books.

Petts, Judith. 1994. Effective waste management: Understanding and dealing with public concerns. Waste Management \& Research 12:207-222.

Portney, Kent E. 1985. The potential of the theory of compensation for mitigating public opposition to hazardous waste treatment facility siting: Some evidence from five Massachusetts commu nities. Policy Studies Journal I :81-89.

Rosa, Eugene A., and William R. Freudenburg. 1993. The historical development of public reactions to nuclear power: Implications for nuclear waste policy. In Public Reactions to nuclear waste, eds. R. E. Dunlap, M. E. Kraft, and E. A. Rosa, pp. 291-324. Durham, NC, and London: Duke University Press.

Sigmon, Brent E. 1987. Achieving a negotiated compensation agreement in siting: The MRS case. Journal of Policy Analysis and Management 2:170-179.

Slovic, Paul. 1987. Perception of risk. Science 236:280-285.

Slovic, Paul, James H. Flynn, and Mark Layman. 1991. Perceived risk, trust, and the politics of nuclear waste. Science 13:1603-1607.

van der Pligt, Joop. 1992. Nuclear energy and the public. Oxford, UK, and Cambridge, MA: Blackwell.

Vari, Anna, Ray Kemp, and Jeryl L. Mumpower. 1991. Public concerns about LLRW facility siting: A comparative study. Journal of Cross-Cultural Psychology 1:83-102. 
